\title{
The Flipped Classroom Model to Develop Egyptian EFL Students' Listening Comprehension
}

\author{
Samah Zakareya Ahmad ${ }^{1}$ \\ ${ }^{1}$ Faculty of Education, Suez University, Suez, Egypt \\ Correspondence: Samah Zakareya Ahmad, Faculty of Education, Suez University, Suez, Egypt. E-mail: \\ samahzakareya@yahoo.com
}

Received: May 19, 2016 Accepted: August 4, 2016 Online Published: August 12, 2016

doi: 10.5539/elt.v9n9p166 URL: http://dx.doi.org/10.5539/elt.v9n9p166

\begin{abstract}
The present study aimed at investigating the effect of the flipped classroom model on Egyptian EFL students' listening comprehension. A one-group pre-posttest design was adopted. Thirty-four $3^{\text {rd }}$-year EFL students at the Faculty of Education, Suez University, were pretested on listening comprehension before the experiment and then posttested after it. Using the flipped classroom model went through three successive stages: planning (where content was prepared and participants were oriented to the flipped classroom process), implementation (that included the pre, during, and after class parts of the flipped classroom model), and evaluation (where group projects were presented and evaluated). Paired-samples t-test revealed a statistically significant improvement in participants' listening comprehension $(\mathrm{t}=11.341, \mathrm{p}<0.05)$ between the pretest and the posttest in favor of the posttest. Therefore, it was concluded that the flipped classroom had a significant effect on the listening comprehension of Egyptian EFL students. Some recommendations and suggestions for further research were introduced.
\end{abstract}

Keywords: Egyptian EFL students, flipped classroom model, listening comprehension

\section{Introduction}

\subsection{Background to the Study}

Listening is an important life skill. It is also important for obtaining comprehensible input that is necessary for language development. According to Lin (2002), learners with good listening comprehension abilities are more capable of participating efficiently in class. Therefore, language teachers should make more effort to improve their students' listening comprehension.

Despite the importance of understanding spoken English, many EFL students have much difficulty to cope with academic listening material (Otte, 2006). This might be due to the difficult nature of listening (Gonen, 2009) or due to the fact that listening was the most neglected and the least well taught of the four language skills (Brownell, 2013). In the Egyptian context, many studies found weaknesses in Egyptian EFL students' listening comprehension at the primary (e.g., Ahmed, 2014; Hassan, 2015), preparatory (e.g., Abo El-kassem, 2009; Al-Ammary, 2015), and secondary stages (e.g., Amin, 2012; Genaidy, 2011) in addition to the college level (e.g., Al-Tonsi, 2013; Salem, 2014). As an assistant professor of TEFL at the Faculty of Education, Suez University, the researcher noticed that most of her students did not have the listening comprehension skills necessary for academic achievement. Therefore, she tested a group of EFL students and found that many of them have problems in listening comprehension.

\subsection{Problem Statement}

The problem of this study was that there were some weaknesses in Egyptian EFL students' listening comprehension. In order to find a solution for this problem, the present study attempted to use the flipped classroom model.

\subsection{Review of Related Literature}

The traditional lecture is becoming an outmoded style of teaching (Datig \& Ruswick, 2013) requiring students to retain bits of information that may later be forgotten (Giannakos \& Chrisochoides, 2014). For Boyer (2013), it seems ironic that so much time is spent in class lecturing, and then students are sent home to struggle through the 
real work without any support. Taylor and Parsons (2011) add that over the last twenty years, learners' needs, goals, and learning preferences have changed. According to Vaughan (2014), these learners often have easy and quick access to information and prefer to learn in active and collaborative environments. Therefore, as Pierce (2013) points out, advances in technology, growth of available online content, and developments in cognitive science challenge traditional notions of teaching and learning. An innovative model which has restructured the traditional lesson (Giannakos \& Chrisochoides, 2014) utilizing internet technology and online educational resources (Strayer, 2012) to support education is the flipped classroom (Horn, 2013).

The flipped classroom-sometimes called reverse (Halili \& Zainuddin, 2015), backwards (McLaughlin et al., 2014), inverted (Bates \& Galloway, 2012), and upside down (Zhang, Ma, \& Liu, 2014) classroom-is an instructional model that inverts the traditional lecture-plus-homework format (Arnold-Garza, 2014). That is, the tasks traditionally assigned as homework are now accomplished inside the classroom and the tasks traditionally accomplished in class are now accomplished at home (Bergmann \& Sams, 2012). The flipped classroom can also be viewed as providing internet resources that facilitate student preparation for classroom study, which is then devoted to application and consolidation (The Queensland Government, 2012). In the flipped classroom, students access the curricular content outside of class (Abeysekera \& Dawson, 2015; Johnson, 2012) in the form of video lessons, so that when they get to class they can get into a real workshop (Boyer, 2013) of hands-on activities and application of knowledge (Ash, 2012; Demski, 2013) that engage them more directly in their learning (Horn, 2013).

\subsubsection{Theoretical Foundations of the Flipped Classroom}

flipped classroom model seems to rest upon a number of theoretical foundations. The first of these foundations is the blended learning approach (Abeysekera \& Dawson, 2015). As it moves the lecture away from class into online delivery and uses face-to-face class time for actual application (Hill, 2012), flipping accords with the idea that blended learning lets students choose the location where they receive content as well as gives them control over the pace at which they receive the online elements (Staker \& Horn, 2012). The second foundation of the flipped model is the student-centered approach (Clark, 2015). Moving learners away from an instructor-centered learning environment (Johnson, 2012) to another environment where teachers become real organizers, mentors, and facilitators (Zhang et al., 2014), the flipped classroom makes each student responsible for coming to class with a basic understanding of the material (Bergmann \& Sams, 2012), so that he/she can engage in interactive learning in the classroom (William \& Wuensch, 2016). A third theoretical underpinning for the flipped classroom is active learning (Lemmer, 2013) which covers a number of pedagogies focusing on student activity and engagement in the learning process (Prince, 2004). The flipped classroom can be used to include active learning elements in class while maintaining the ability to cover critical course material (Leicht, Zappe, Messner, \& Litzinger, 2012).

\subsubsection{History of the Flipped Classroom}

The concept of the flipped classroom originated in the early 1990s through an effort led by Harvard University professor Erik Mazur who let each student choose content that met his/her individual needs from text files, interactive demonstrations, and problem solutions (Mazur, 1991). In 1998, Walvoord and Anderson proposed a model in which students gained first-exposure learning prior to class and focused on the processing part of learning during class. In 2000, Lage, Platt, and Treglia explained that inverting a classroom means that actions that have traditionally happened inside the classroom now happen outside it. In 2001, Massachusetts Institute of Technology (MIT) designed Open Educational Resources providing learning resources such as books and videos, a step that has influenced the emergence of the flipped classroom model several years later (Bishop \& Verleger, 2013).

At the end of 2004, Salman Khan, an MIT graduate, began explaining math through recorded videos and placed them on YouTube (Bowen, 2012). In 2008, he created a library of free online tutoring videos containing a variety of academic subjects, known as the Khan Academy, which may be viewed as a touchstone of the flipped classroom technique (Ash, 2012). In 2007, two science teachers from Colorado, Jonathan Bergmann and Aaron Sams, tried to record video lectures for students who had missed class (Fulton, 2012). They required the students to take notes on the videos and come to class with one thoughtful question to share. The teachers noticed an improvement in test scores for students using the flipping technique (Ash, 2012). It was not long before other students and teachers throughout the world were using these lessons, and making their own (Tucker, 2012). The model was, then, gradually accepted and popularized (Zhang et al., 2014). It has even attracted the attention of funders such as the Bill and Melinda Gates Foundation, which has become a major backer of Khan Academy (Tucker, 2012). 


\subsubsection{Advantages of the Flipped Classroom}

The flipped classroom possesses the best qualities of both the lecture model and the active learning model (Toto \& Nguyen, 2009). This might be the reason that it is gaining support at all levels of education (Hoffman, 2014). One of the advantages of the flipped model is that classroom time can be used more efficiently and creatively (Fulton, 2012). As it utilizes online resources to move lectures outside the classroom, class time is freed up for active learning endeavors such as discussion and problem solving, rather than passive listening (Arnold-Garza, 2014; Milman, 2012). Another advantage of the flipped classroom is the increasing opportunity for interaction between the teacher and students (Bergmann, Overmayer, \& Willie, 2013). Since it maximizes face-to-face time (Pape, Sheehan, \& Worrell, 2012) and focuses on classroom interactive discussion (Millard, 2012), the flipped classroom helps learners to be capable of clearing up any confusion immediately as well as helps the teacher to be able to monitor learners' performance (Lage et al., 2000).

The flipped classroom offers many other advantages for learners. It increases their academic performance (Davies, Dean, \& Ball, 2013), creates an environment that responds to their preferences (Lemmer, 2013), and provides a content that is designed according to their needs (Bergmann et al., 2013). Moreover, the use of video puts lectures under the learners' control, allowing them to watch, rewind, and fast-forward as they need (Educause Learning Initiative, 2012). This makes content more accessible (Acedo, 2013) for students who cannot attend class (Halili \& Zainuddin, 2015) as well as for students with accessibility concerns (Educause Learning Initiative, 2012). Moreover, the flipped classroom increases students' engagement (Millard, 2012), freedom (Fulton, 2012), control (Acedo, 2013), responsibility for learning (Pape et al., 2012), autonomy (Driscoll \& Petty, 2014), collaboration (Acedo, 2013), motivation, and confidence (Lemmer, 2013). It also changes students' attitudes toward learning (Zhang et al., 2014), allows them to learn at their own pace (Fulton, 2012), shifts them from passive to active learners (Sankey \& Hunt, 2013), offers them flexibility (Johnson, 2012), and gives greater ownership over their learning (Horn, 2013).

\subsubsection{Components of the Flipped Classroom}

Although there is no one way to flip a course (Dewey, 2013), a flipped classroom teaching model has two components: (1) direct instruction using video lectures while outside the class and (2) active face-to-face learning while inside the class (Sharples et al., 2014). The video lecture is often seen as the essential ingredient in the flipped approach (Educause Learning Initiative, 2012). However, it is not the videos on their own that makes the difference, but how the teacher integrates them into an overall approach (Tucker, 2012). Such lecture can either be recorded by the teacher and uploaded to the Internet or selected from websites (e.g., YouTube EDU, the Khan Academy, \& PBS) (Halili \& Zainuddin, 2015). Some teachers let students watch videos in class, while others assign these videos for homework (Ash, 2012). In general, when teachers think about the videos they use to provide content before class, they must ensure that these videos are enhancing their lessons (Dewey, 2013). Some guidelines can be introduced regarding the use of video lectures in flipped classrooms. The first guideline is that the videos should be short (Bergman \& Sams, 2012) because lengthy videos can double the students' workload without necessarily providing added value (Slomanson, 2014). In this respect, Raths (2014) suggests that the long video should be broken up into sections with interactive elements. Another guideline is that the video lecture should be interactive (Bergman \& Sams, 2012). Ash (2012) advises teachers to find a way to engage students in the videos such as requiring students to take notes on the videos, ask questions about the videos, or engage in discussion about them.

The flipped classroom is more than publishing a video lecture on the Internet. Therefore, teachers ought to pay attention to the other component of the flipped classroom: class time (Slomanson, 2014). The success of flipping depends on how the classroom element is structured (Sharples, et al., 2014). In this respect, Bergmann and Sams (2014) point out that the flipped classroom model has established less lecturing and more activity in the classroom. For example, Rapoport (2013) recommends using classroom time to answer questions students have about the basic material while Maher, Lipford, and Singh (2013) suggest that students spend time in the classroom working on activities that create a learning environment of collaboration with peers. Sharples, et al. (2014) add that the classroom environment in the flipped model should be set up to reflect and encourage a shift towards collaboration and group work.

\subsubsection{Teachers' and Students' Perceptions about the Flipped Classroom}

Some studies investigated the perceptions of teachers and students about the flipped classroom. Concerning teachers, Maloy, Edwards, and Evans (2014) found that higher education faculty members who conducted flipped classes reported remarkable teaching and learning impacts. Another experience is that of Van Veen (2013) who discovered that flipping has been the most transformative experience of his career. He even doubted that he 
would be able to go back to teaching in the traditional paradigm. Also, Linga and Wang (2014) described their experiment using flipped class learning as a learning curve for them. Moreover, Corrias (2014) found out that with the flipped approach, classroom sessions turned out to be livelier than he expected.

Concerning students' perceptions about the flipped classroom, many studies found strong indications of students being appreciative of such teaching model. For example, in the study conducted by Butt (2014), 75\% of students had a positive view of flipped instruction. Moreover, results of a survey conducted by McLaughlin et al. (2013) at the beginning and end of a flipped course revealed that significantly more learners preferred the flipped format after the completion of the course than before it. Another survey administered by Pierce and Fox (2012) revealed that $96 \%$ of the respondents agreed that viewing video lectures before class was important, $79 \%$ agreed that increased teacher-student interaction was desirable, and $62 \%$ expressed a desire for more teachers to use the flipped model. In the study of Maher et al. (2013), students generally found flipping to be a more enjoyable learning experience while in the study of Baker (2000), they had a positive perception toward the model, indicating that online resources provided them more control over their learning. Moreover, comments on a survey administered by Ruddick (2012) suggested that students found the online video and PowerPoint materials useful. Furthermore, the feedback Johnson (2012) received about the flipped classroom from students and parents was overwhelmingly positive.

\subsubsection{Teachers' and Students' Roles in the Flipped Classroom}

The flipped classroom represents a role change for the teacher (Educause Learning Initiative, 2012) from transmitting information during class time to guiding learners through a variety of active learning exercises (Morrison, 2014). By using a flipped classroom, the teacher does not have to lecture for hours while students listen and take notes (Bergmann \& Sams, 2012). Therefore, in the flipped model, teachers work more intensively with students (Carpenter \& Pease, 2012), guide them to the content (Bergmann \& Sams, 2012), provide practical assistance (Boyer, 2013), assist them in applying what they have learned online (Horn, 2013), encourage them in individual or collaborative efforts, and challenge them to think creatively (Bergmann \& Sams, 2012).

As for students, the flipped paradigm treats them as active learners who reconstruct knowledge from information (Van Veen, 2013). They receive the same instructional content the professor would give in person, but the focus is on doing things with the information rather than sitting passively and watching someone else demonstrate (Connor, 2012). Students gather the information largely outside of class and when in class, they apply what they have learned to new contexts (Berrett, 2012). Flipping provides additional time for them to work out problems, while having the instructor there as a guide (Leicht et al., 2012). Therefore, Bergmann and Sams (2012) remind educators that the true essence of the flip is really to focus on the student.

\subsection{Hypothesis of the Study}

There would be a statistically significant difference $(\alpha \leq 0.05)$ in third-year EFL majors' listening comprehension between the pretest and the posttest in favor of the posttest.

\subsection{Objectives of the Study}

The present study aimed at finding answers to the following questions:

- How can the flipped classroom model help to develop Egyptian EFL student's listening comprehension?

- Is there any significant difference $(\alpha \leq 0.05)$ in third-year EFL majors' listening comprehension between the pretest and the posttest?

\section{Method}

\subsection{Research Design}

A one-group pre-posttest quasi-experimental design was employed. Students were pretested on listening comprehension before the treatment and then posttested after it. Differences between the pretest and the posttest were evaluated.

\subsection{Variables}

The study included an independent variable (the flipped classroom model) as well as a dependent variable (listening comprehension). Operational definitions of both variables are listed below.

\subsubsection{The Flipped Classroom Model}

The flipped classroom model is operationally defined as an instructional model in which students receive basic knowledge through online videos and then answer a quiz on them before class. During class, students ask and answer questions about the content and engage in active learning activities where they practice what they learned 
from the online videos they viewed. After class, students reflect on their experience before and during class in an online discussion forum and work on a group project that provides additional practice opportunities.

\subsubsection{Listening Comprehension}

Listening comprehension is operationally defined as the process of understanding, interpreting, and evaluating the spoken language as manifested in EFL students' ability to: 1) recognize the main idea, 2) guess the meaning of unfamiliar words from context, 3) identify the type of speech, 4) listen for details, 5) understand supporting ideas, 6) recognize degree of certainty, 7) recognize purpose, 8) understand sequencing of ideas, 9) understand cause and effect, and 10) differentiate fact from opinion.

\subsection{Participants}

Participants were 34 third-year EFL majors at the Faculty of Education, Suez University. All participants spent at least 10 years learning EFL. They all ranged between 19-21 years of age.

\subsection{Measure}

A listening comprehension test was devised by the researcher and it consisted of two parts. In part A, students listened to 20 short conversations and answered a question after each conversation. In part B, they heard two long conversations and answered 10 questions on them. All questions were multiple-choice with four options and they covered the skills mentioned in the adopted definition of listening comprehension. All questions were equally weighed. The total score of the test was 30 points, one point for each question. Five experts in the field of TEFL were relied on for their opinions on the appropriateness of the test items. The researcher achieved criterion validity through calculating Pearson's Coefficient of correlation between the scores of a group of third-year EFL students on both the listening comprehension test and the listening part of the Cambridge Key English Test (KET). The coefficient of correlation was 0.91 . Test-retest reliability was achieved through administering the test twice, with a 14-day time span. Pearson's Coefficient of correlation between the two administrations was 0.79 . Both correlation coefficients were significant at the 0.05 level.

\subsection{Procedures}

The experimental procedures of the present study were carried out at the Faculty of Education, Suez University, during the second term of the 2015/2016 academic year within the "Using Computers in Teaching EFL" course. These procedures were executed in three successive stages: 1) pretesting, 2) using the flipped classroom and 3) posttesting. As for pretesting and posttesting, the listening comprehension test was administered to all participants before and after implementing the flipped classroom, respectively. As for using the flipped classroom, it lasted for 12 weeks and went through three phases: planning, implementation, and evaluation, as illustrated in Figure 1. 


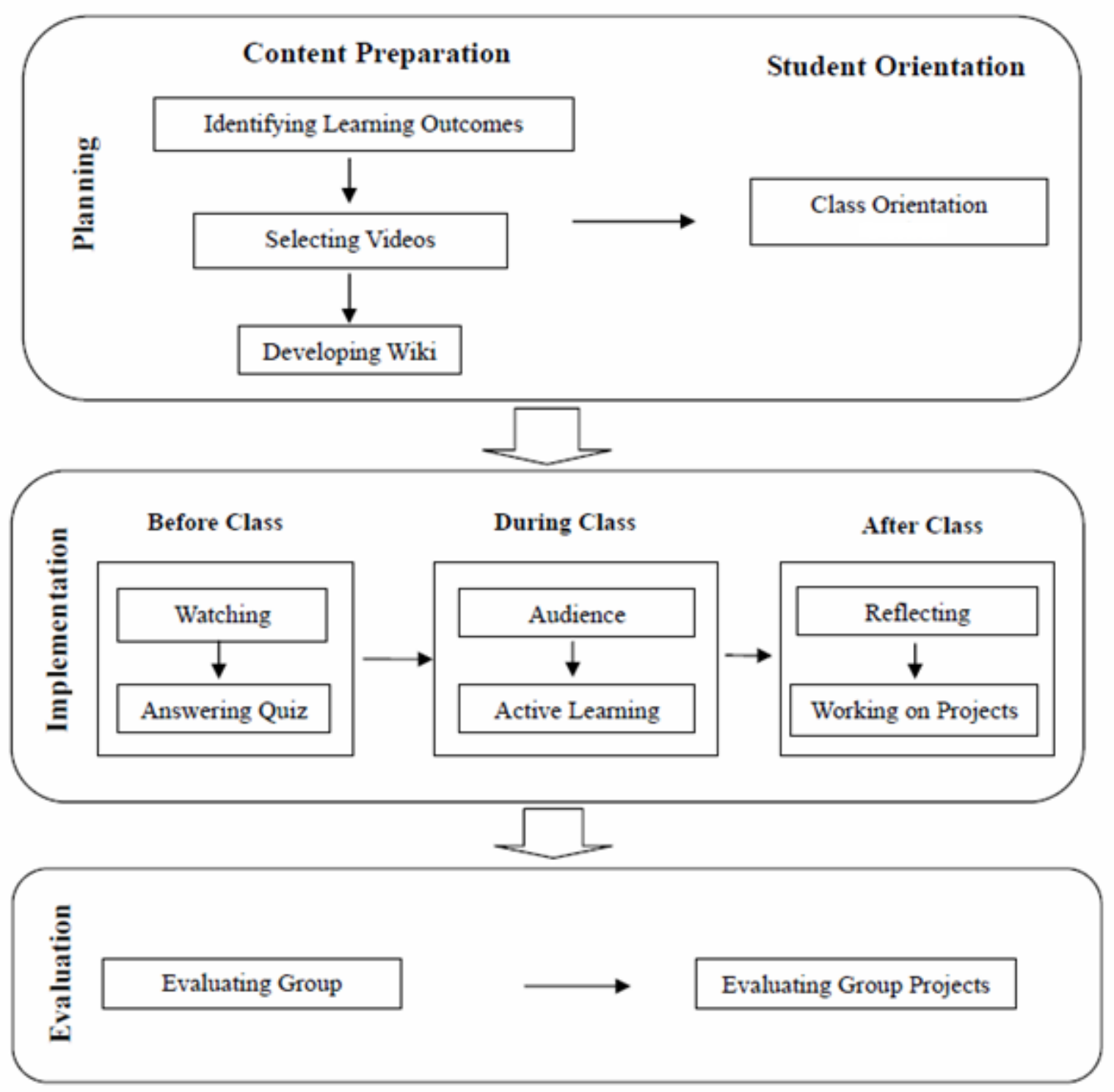

Figure 1. Flipped classroom process

\subsubsection{Planning for the Flipped Classroom}

This phase consisted of two parts: content preparation and student orientation. In order to prepare the content, course objectives were identified, learning outcomes for each lecture were developed, and content coverage was determined. All the knowledge or skill points in each lecture were introduced in mini videos (for faster viewing and download times). Each video lasted 10-15 minutes, with a total of 50-60 minutes for each lecture and a total viewing time for all 12 lectures of 11.6 hours. As Lawrence (cited in Sankey \& Hunt, 2013) puts it, there are experts all over the world and there is little point in reinventing the wheel by creating more resources. Therefore, the researcher utilized video resources from many websites such as TED (www.ted.com) and YouTube.

Because almost all participants were not accustomed to the flipped classroom experience, a comprehensive syllabus which included a detailed description of the course was placed on a wiki. This provided students a quick and easy access to all the materials of the course and allowed them to interact, share viewpoints, and organize content. It also enabled the researcher to revise content to reflect new topics and student interests throughout the semester.

During a class orientation session that lasted 65 minutes, the researcher introduced the notion of the flipped classroom, explained the basic ideas, and demonstrated how to operate online. This included the structure and functions of the wiki, how to deal with the assigned videos (e. g., replay, stop, or jump to certain points), and 
how to search for more videos. The session also included the requirements for online interaction, the explanation of some examples, and answers to students' questions.

\subsubsection{Implementation of the Flipped Classroom}

This phase consisted of three parts: before, during, and after class according to the adopted definition of the flipped classroom model.

\subsubsection{Before Class}

This preparation part was divided into two main components: watching videos and answering online quizzes. Each week, students watched the short videos assigned for the next lecture in order to obtain the basic knowledge before class. They had the opportunity to comment on each video and discuss problematic parts. For the three students with no Internet access at their homes, media was made available on flash drives and CDs. One student was still unable to view the content at home; therefore, she came to class early to watch the videos on the researcher's laptop.

In order to increase the likelihood that students would come prepared for class, each of the short videos was followed by an online quiz, designed to record each student's participation, give him/her more opportunities to review what he/she has learned, and offer him/her immediate feedback on whether he/she missed any essential points. Moreover, the researcher used the results of the quizzes as a launching point for class discussion as well as for adjusting the class plan to address student needs.

\subsubsection{During Class}

In this part, the researcher used the time saved as an opportunity to engage the participants more deeply in the process of learning the main concepts of the lesson and to maximize their learning opportunities in the classroom. It was divided into two main components: the first one focused on receiving audience response through recalling the basic knowledge while the second focused on engaging participants with active learning and critical thinking processes. First, the researcher began class time by asking questions, both to assess participants' understanding of the basic concepts presented in the assigned videos and to determine the best use of class time. She also invited questions from participants that addressed content provided in the videos. Sometimes, the instructor asked the participants to address each other's questions. In addition, the instructor reviewed her participants' performance in the online quiz and addressed any points of perceived confusion.

Receiving students' responses lasted 15-20 minutes then the researcher used the time remaining in the lecture period to apply concepts from the videos. She engaged the participants with the course material through student-centered active learning activities where they created, collaborated, and put into practice what they learned from the lectures they viewed outside class. A variety of active learning activities were used (e.g., 3-2-1, write-pair-share, debates, concept mapping, note comparison/sharing, minute papers, jigsaw, learning by teaching, fishbowl, three-step interview). See Appendix for a brief description of each of these activities.

\subsubsection{After Class}

This part focused on reflection and project work. At home, participants logged into an online discussion forum where they reflected on their experience with the videos they watched as well as the active learning sessions. The researcher directed the reflection process by recommending responding to questions such as: "Did you like the flipped class?", "What questions do you still have about the topic or exercise?", and "What suggestions do you have for improving the activity?" Moreover, participants had the opportunity to post questions for the researcher to answer.

Concerning project work, participants were divided into groups of three to four and the researcher assigned a project at the beginning of the term. This project provided additional practice opportunities, encouraged higher-order thinking, and assessed participants' ability to analyze, synthesize, and evaluate the material they acquired from the course. The project required them to design a technological tool that could be used in teaching as well as plan a lesson using this tool. At the beginning of the course, the instructor posted examples of the project to the course wiki. She also offered support through the discussion forum.

\subsubsection{Evaluation of the Flipped Classroom}

Participants submitted their projects two weeks before the final submission for additional critique so that improvements could be made before final presentation. During a class session, participants presented their projects. The researcher evaluated the projects as well as encouraged participants to self and peer assess these projects. 


\section{Result}

Paired-samples t-test was used to test the difference between the means of scores of the participants on the pretest and the posttest of listening comprehension. This difference was statistically significant $(\mathrm{t}=11.341$, $\mathrm{p}<0.05$ ); see Table 1. Using Cohen's (1988) formula, effect size for this difference was 1.30. This effect size is considered "large" according to Feldt (as cited in Hinkle, Wiersma, \& Jurs, 1994, p. 316).

Table 1. Paired-samples t-test of the difference between the means of scores of the participants on the pretest and the posttest of listening comprehension

\begin{tabular}{lllllll}
\hline & \multicolumn{2}{l}{ Paired Differences } & t & df & Probability \\
\cline { 2 - 4 } Posttest-Pretest & Mean & Std. Deviation & Std. Error Mean & & & \\
\cline { 2 - 4 } & 7.559 & 3.886 & .666 & 11.341 & 33 & Significant \\
\hline
\end{tabular}

\section{Discussion}

In the present study, it was hypothesized that there would be a statistically significant difference $(\alpha \leq 0.05)$ in third-year EFL majors' listening comprehension between the pretest and the posttest in favor of the posttest. A paired-samples t-test revealed a statistically significant difference in favor of the posttest $(t=11.341, p<0.05)$. A probable reason for the result reached in this study may be that the flipped classroom required participants to watch videos before class that explained the content of each lecture. They had to listen attentively to these videos in order to answer the online quiz as well as to gain a basic background about the content that would enable them to participate effectively in classroom discussion. Here, it can be argued that watching these videos could have improved the listening comprehension of the participants for three reasons. First, listening to native speakers could have made participants aware of the difficulties of understanding spoken authentic English. This might have led them to try harder to enhance their listening comprehension skills. Second, the presence of non-verbal communication features (e.g., facial expressions \& gestures) could have been useful for participants in comprehending the listening material. Third, the technical features of videos (e.g., pausing, reviewing, etc.) might have provided participants with opportunities for analyzing and comprehending the language presented. In this respect, many studies found that the use of videos improves listening comprehension (e.g., Kuo, 2009; Sarani, Behtash, \& Arani, 2014; Wagner, 2010).

Another characteristic of the flipped classroom that could explain its effectiveness in improving listening comprehension is the active learning component. In the present study, class time was used in engaging participants in active learning activities based on collaboration, interaction, and discussion in English which might have improved participants' listening comprehension. This explanation goes along with Jones's (2006) assertion that collaborative activities have long been shown to enhance learners' comprehensible input which, in turn, leads to greater understanding of aural texts. It also goes along with the findings of some studies that found that active learning improves listening comprehension (e.g., Ashraf, Fatemi, \& Naderi, 2013).

\section{Conclusion}

Based on the result of the present study, the researcher concluded that the flipped classroom model improved the listening comprehension of EFL students. This instructional model could be used in other courses or implemented by other teachers at Suez University or other tertiary institutions.

\section{Recommendations and Suggestions}

Based on the result of the present study, the researcher recommends: 1) using flipped classrooms for enhancing EFL learners' listening comprehension, 2) encouraging EFL learners to use available learning resources on the internet, 3) providing them adequate opportunities to listen to authentic material, and 4) devoting class time to active learning, rather than lecturing. Moreover, the researcher suggests conducting studies tackling: 1) the impact of the flipped model on EFL critical listening, 2) EFL learners' attitude towards using flipped classrooms in education, 3) the impact of other online tools (e.g., e-mails, discussion boards, weblogs) on listening comprehension, and 4) the impact of the flipped model on EFL learners' self-directed learning.

\section{Acknowledgments}

Sincere thanks go to Professor Dr. Ahmed Hassan Seifeddin for his assistance and encouragement. 


\section{References}

Abeysekera, L., \& Dawson, P. (2015). Motivation \& cognitive load in the flipped classroom: Definition, rationale, \& a call for research. Higher Education Research \& Development, 34(1), 1-14. http://dx.doi.org/10.1080/07294360.2014.934336

Abo El-kassem, A. (2009). The effectiveness of using the storytelling approach in developing listening skills in English language for pupils of the preparatory stage (Unpublished master's thesis). Cairo University, Egypt.

Acedo, M. (2013). Ten pros \& cons of a flipped classroom. Retrieved March 13, 2015, from http://www.teachthought.com/uncategorized/10-pros-cons-flipped-classroom/

Ahmed, W. (2014). Developing sixth primary students' English listening skills by using some authentic assessment techniques (Unpublished master's thesis). Suez Canal University, Egypt.

Al-Ammary, A. (2015). The effectiveness of a program based on podcasting in developing some EFL listening comprehension skills among preparatory stage students (Unpublished master's thesis). South Valley University, Egypt.

Al-Tonsi, H. (2013). The effectiveness of using blended learning in developing English majors' listening comprehension skills at faculties of education (Unpublished doctoral dissertation). Suez Canal University, Egypt.

Amin, E. (2012). The effectiveness of using the cognitive academic language learning approach in developing strategic listening \& listening comprehension skills among secondary school students (Unpublished doctoral Dissertation). Banha University, Egypt.

Arnold-Garza, S. (2014). The flipped classroom: Assessing an innovative teaching model for effective \& engaging library instruction. College \& Research Libraries News, 75(1), 10-13.

Ash, K. (2012). Educators view flipped model with a more critical eye. Education Week, 32(2), S6-S7.

Ashraf, H., Fatemi, M., \& Naderi, S. (2013). The effect of active learning instruction on the intermediate Iranian EFL learners' listening comprehension ability. International Journal of Linguistics, 5(5), 225-242. http://dx.doi.org/10.5296/ijl.v5i5.4264

Baker, J. (2000, April). The classroom flip: Using web course management tools to become a guide by the side. Paper presented at the $11^{\text {th }}$ International Conference on College Teaching \& Learning, Jacksonville, FL.

Bates, S., \& Galloway, R. (2012, April). The inverted classroom in a large enrolment introductory physics course: A case study. Paper presented at the HEA STEM Conference, London, United Kingdom.

Bergmann, J., Overmyer, J., \& Wilie, B. (2013, July 9). The flipped class: What it is \& what it is not. The Daily Riff. Retrieved July 11, 2015, from http://www.thedailyriff.com/articles/the-flipped-class-conversation-689.php

Bergmann, J., \& Sams, A. (2012). Flip your classroom: Reach every student in every class every day. Washington, DC: International Society for Technology in Education. http://dx.doi.org/10.1111/teth.12165

Bergmann, J., \& Sams, A. (2014). Flipped learning: Maximizing face time. Training \& Development, 68(2), 28-31.

Berrett, D. (2012). How flipping the classroom can improve the traditional lecture. Education Digest, 78(1), 36-41.

Bishop, J., \& Verleger, M. (2013, June). The flipped classroom: A survey of the research. Paper presented at the $120^{\text {th }}$ ASEE Annual Conference, Atlanta, GA.

Bowen, J. (2012). Teaching naked: How moving technology out of your college classroom will improve student learning. San Francisco: John Wiley \& Sons.

Boyer, A. (2013). The flipped classroom: Catering for difference. Teacher Learning Network, 20(1), 28-29.

Brownell, J. (2013). Listening: Attitudes, principles, \& skills (5th ed.). New York: Routledge.

Butt, A. (2014). Student views on the use of a flipped classroom approach: Evidence from Australia. Business Education \& Accreditation, 6(1) 33-43.

Carpenter, J., \& Pease, J. (2012). Sharing the learning. Phi Delta Kappan, 49(2), 36-41. http://dx.doi.org/10.1177/003172171209400209

Clark, K. (2015). The effects of the flipped model of instruction on student engagement \& performance in the secondary mathematics classroom. Journal of Educators Online, 12(1), 91-115. 
Cohen, J. (1988). Statistical power analysis for the behavioral sciences (2nd ed.). Hillsdale, NJ: Lawrence Earlbaum.

Connor, K. (2012). Goodbye, Podium: An engineering course puts theory into practice. Chronicle of Higher Education, 59(6), B30-B31.

Corrias, A. (2014). Lightening up mathematics-intensive classes: A case study using a flipped classroom approach. CDTL Brief, 17(1), 10-13.

Datig, I., \& Ruswick, C. (2013). Four quick flips: Activities for the information literacy classroom. College \& Research Libraries News, 7(5), 249-251 \& 257.

Davies, R., Dean, D., \& Ball, N. (2013). Flipping the classroom \& instructional technology integration in a college-level information systems spreadsheet course. Educational Technology Research \& Development, 61(4), 563-580. http://dx.doi.org/10.1007/s11423-013-9305-6

Demski, J. (2013). Six expert tips for flipping the classroom. Campus Technology, 25(5), 32-37.

Dewey, M. (2013). The upside-down classroom: How the flipped lecture model can be used in legal education. Workshop held at the Institute for Law Teaching \& Learning Conference, June 7-9, 2013, Topeka, Kansas. Retrieved May 19, 2015 from http://law.sc.edu/carolinaslrw/materials/Dewey-CCLRW_flipped_lecture.pdf

Driscoll, T., \& Petty, K. (2014). Student-driven education with flipped learning \& 20-time. In L. Kyei-Blankson, \& E. Ntuli (Eds.), Practical applications \& experiences in K-20 blended learning environments (pp. 120-136). Hershey, PA: Information Science Reference. http://dx.doi.org/10.4018/978-1-4666-4912-5.ch009

Educause Learning Initiative. (2012). Seven things you should know about flipped classrooms. Retrieved August 23, 2015, from https://net.educause.edu/ir/library/pdf/ELI7081.pdf

Fulton, K. (2012). Upside down \& inside out: Flip your classroom to improve student learning. Learning \& Leading with Technology, 39(8), 12-17.

Genaidy, F. (2011). The effect of using students journals on developing listening comprehension skills in English for the first year secondary school students (Unpublished master's thesis). Helwan University, Egypt.

Giannakos, M., \& Chrisochoides, N. (2014). Challenges \& perspectives in an undergraduate flipped classroom experience: Looking through the lens of learning analytics. Proceedings of Frontiers in Education Conference (pp. 1-5). Madrid: IEEE. http://dx.doi.org/10.1109/FIE.2014.7044449

Gonen, M. (2009). The relationship between FL listening anxiety \& FL listening strategies: The case of Turkish EFL learners. Proceedings of the $5^{\text {th }}$ WSEAS/IASME International Conference on Educational Technologies, July 1-3, 2009 (pp. 44-49). University of La Laguna, Spain.

Halili, S., \& Zainuddin, Z. (2015). Flipping the classroom: What we know \& what we don't. The Online Journal of Distance Education \& e-Learning, 3(1), 15-22.

Hassan, H. (2015). The effect using some learning techniques on developing primary pupils' listening skills (Unpublished master's thesis). Ain Shams University, Egypt.

Hill, P. (2012). Online educational delivery models: A descriptive view. Educause Review, 47(6), 84-86, 88, 90, 92 , 94-97.

Hinkle, D., Wiersma, W., \& Jurs, S. (1994). Applied statistics for the behavioral sciences (3rd ed.). Boston: Houghton Mifflin.

Hoffman, E. (2014). Beyond the flipped classroom: Redesigning a research methods course for E3 instruction. Contemporary Issues in Education Research, 7(1), 51-62. http://dx.doi.org/10.19030/cier.v7i1.8312

Horn, M. (2013). The Transformational potential of flipped classrooms: Different strokes for different folks. Education Next, 13(3), 78-79.

Johnson, G. (2012). Students, please turn to YouTube for your assignment. Education Canada, 52(5), 16-18.

Jones, L. (2006). Effects of collaboration \& multimedia annotations on vocabulary learning \& listening comprehension. CALICO Journal, 24(1), 33-58. http://dx.doi.org/10.1558/cj.v24i1.33-58

Kuo, L. (2009). The effects of YouTube listening/viewing activities on Taiwanese EFL learners' listening comprehension (Unpublished doctoral dissertation). La Sierra University.

Lage, M., Platt, G., \& Treglia, M. (2000). Inverting the classroom: A gateway to creating an inclusive learning environment. Journal of Economic Education, 31(1), 30-43. http://dx.doi.org/ 10.2307/1183338 
Leicht, R., Zappe, S., Messner, J., \& Litzinger, T. (2012). Employing the classroom flip to move lecture out of the classroom. Journal of Applications \& Practices in Engineering Education, 3(1), 19-31.

Lemmer, C. (2013). A view from the flip side: Using the inverted classroom to enhance the legal information literacy of the international LL.M. student. Law Library Journal, 105(4), 461-491.

Lin, L. (2002). The effects of feature films upon learners' motivation, listening, \& speaking skills: The learner-centered approach. Retrieved from ERIC database. (ED 470811)

Linga, P., \& Wang, C. (2014). Flipped class learning in a large class setting. CDTL Brief, 17(1), 4-9.

Maher, M., Lipford, H., \& Singh, V. (2013). Flipped classroom strategies using online videos. Technical Report, Center for Education Innovation, University of North Carolina, Charlotte. Retrieved May 15 2015, from http://cei.uncc.edu/sites/default/files/CEI\%20Tech\%20Report\%203.pdf

Maloy, R., Edwards, S., \& Evans, A. (2014). Wikis, workshops, \& writing: Strategies for flipping a college community engagement course. Journal of Educators Online, 11(1), 1-23.

Mazur, E. (1991). Can we teach computers to teach? Computers in Physics, 5(1), 31-38. http://dx.doi.org/10.1063/1.4822968

McLaughlin, J., Griffin, L., Esserman, D., Davidson, C., Glatt, D., Roth, M., ... Mumper, R. (2013). Pharmacy student engagement, performance, \& perception in a flipped satellite classroom. American Journal of Pharmaceutical Education, 77(9), 196. http://dx.doi.org/10.5688/ajpe779196

McLaughlin, J., Roth, M., Glatt, D., Gharkholonarehe, N., Davidson, C., Griffin, L., ... Mumper, R. (2014). The flipped classroom: A course redesign to foster learning \& engagement in a health professions school. Academic Medicine, 89(2), 236-243. http://dx.doi.org/ 10.1097/ACM.0000000000000086

Millard, E. (2012). Five reasons flipped classrooms work: Turning lectures into homework to boost student engagement \& increase technology-fueled creativity. University Business, 15(11), 26-29.

Milman, N. (2012). The flipped classroom strategy: What is it \& how can it best be used? Distance Learning, 9(3), 85-87.

Morrison, C. (2014). From sage on the stage to guide on the side: A good start. International Journal for the Scholarship of Teaching \& Learning, 8(1), Article 4. http://dx.doi.org/ 10.20429/ijsotl.2014.080104

Otte, J. (2006). Real language for real people: A descriptive \& exploratory study of the outcomes of aural authentic texts on the listening comprehension of adult English-as-a-second language students enrolled in an advanced ESL listening course. Dissertation Abstracts International: Section B, 67(4), 1246.

Pape, L., Sheehan, T., \& Worrell, C. (2012). How to do more with less: Lessons from online learning. Learning \& Leading with Technology, 39(6), 18-22.

Pierce, R. (2013). Student performance in a flipped class module. In R. McBride, \& M. Searson (Eds.), Proceedings of Society for Information Technology \& Teacher Education International Conference 2013 (pp. 942-954). Chesapeake, VA: AACE.

Pierce, R., \& Fox, J. (2012). Vodcasts \& active-learning exercises in a flipped classroom model of a renal pharmacotherapy module. American Journal of Pharmaceutical Education, 76(10), 196. http://dx.doi.org/ 10.5688/ajpe7610196

Prince, M. (2004). Does active learning work? A review of the research. Journal of Engineering Education, 93(3), 223-231. http://dx.doi.org/10.1002/j.2168-9830.2004.tb00809.x

Rapoport, N. (2013). Rethinking U.S. legal education: No more 'same old, same old'. Connecticut Law Review, 45(4), 1409-1429.

Raths, D. (2014). Nine video tips for a better flipped classroom. Education Digest, 79(6), 15-21.

Ruddick, K. (2012). Improving chemical education from high school to college using a more hands-on approach (Unpublished doctoral dissertation). University of Memphis.

Salem, R. (2014). A web based program for developing EFL students' listening comprehension \& critical speaking skills (Unpublished doctoral dissertation). Suez University, Egypt.

Sankey, M., \& Hunt, L. (2013). Using technology to enable flipped classrooms whilst sustaining sound pedagogy. In H. Carter, M. Gosper, \& J. Hedberg (Eds.), Electric dreams: Proceedings of $30^{\text {th }}$ Ascilite Conference (pp.785-795). Macquire University, Sydney. 
Sarani, A., Behtash, E., \& Arani, S. (2014). The effect of video-based tasks in listening comprehension of Iranian pre-intermediate EFL learners. Gist Education \& Learning Research Journal, 8, 29-47.

Sharples, M., Adams, A., Ferguson, R., Gaved, M., McAndrew, P., Rienties, B., ... Whitelock, D. (2014). Innovating pedagogy 2014: Open University innovation report 3. Milton Keynes: The Open University.

Slomanson, W. (2014). Blended Learning: A flipped classroom experiment. Journal of Legal Education, 64(1), 93-102.

Staker, H., \& Horn, M. (2012). Classifying K-12 blended learning. Innosight Institute. Retrieved July 19, 2015, from http://www.christenseninstitute.org/wp-content/uploads/2013/04/Classifying-K-12-blended-learning.pdf

Strayer, J. (2012). How learning in an inverted classroom influences cooperation, innovation, \& task orientation. Learning Environments Research, 15(2), 171-193. http://dx.doi.org/10.1007/s10984-012-9108-4

Taylor, L., \& Parsons, J. (2011). Improving student engagement. Current Issues in Education, 14(1), 1-33.

The Queensland Government. (2012). The flipped classroom: Classroom connections. Retrieved June 19, 2015, from https://classroomconnections.eq.edu.au/topics/Pages/2012/november/flipped-classroom.aspx

Toto, R., \& Nguyen, H. (2009, October). Flipping the work design in an industrial engineering course. Paper presented at the $39^{\text {th }}$ ASEE/IEEE Frontiers in Education Conference, San Antonio, TX. http://dx.doi.org/10.1109/FIE.2009.5350529

Tucker, B. (2012). The Flipped classroom: Online instruction at home frees class time for learning. Education Next, $12(1), 82-83$.

Van Veen, B. (2013). Flipping signal-processing instruction. Signal Processing Magazine, 30(6), 145-150. http://dx.doi.org/ 10.1109/MSP.2013.2276650

Vaughan, M. (2014). Flipping the learning: An investigation into the use of the flipped classroom model in an introductory teaching course. Education Research \& Perspectives, 41, 25-41.

Wagner, E. (2010). The effect of the use of video texts on ESL listening test-taker performance. Language Testing, 27(4), 493-513. http://dx.doi.org/10.1177/0265532209355668

Walvoord, B., \& Anderson, V. (1998). Effective grading: A tool for learning \& assessment in college. San Francisco: Jossey-Bass.

Williams, S., \& Wuensch, K. (2016). Flipping quantitative classes: A triple win. Decision Sciences: Journal of Innovative Education, 14(1), 67-89. http://dx.doi.org/10.1111/dsji.12088

Zhang, P., Ma, J., \& Liu, Y. (2014). Flipped classroom: An effective model of improving student teachers' educational technology. Journal of Information Technology \& Application in Education, 3(3), 144-149. http://dx.doi.org/ 10.14355/jitae.2014.0303.02

\section{Appendix}

\section{Active Learning Activities}

In general, each classroom session accommodated at least three of the following active learning activities:

1) $3-2-1$

Students were asked to write about the videos they watched before class. They had to write: three things they learned from these videos, two questions they still had, and one aspect of the videos they enjoyed.

2) Write-pair-share

The researcher presented a discussion question in class and then gave students one minute to write out their response. Students then paired up and explained their responses to one another for 3-5 minutes. Finally, as a class, the issue was discussed.

3) Debates

The researcher presented opposing viewpoints, assigned students to debate teams, gave them a position to defend, and then asked them to present arguments in support of their position. Finally, the instructor asked for two or three volunteers to make summary arguments for each side.

4) Concept Mapping

Students were asked to represent the information they got from the videos as circles or boxes connected with 
labeled arrows which indicated the relationship between each set of connected concepts.

\section{5) Note Comparison/Sharing}

Students were informed to take notes during watching the video lectures before class. Then, in class, they were asked to read each others' notes, filling in the gaps in their own note-taking. They were also asked to compare their notes with their partners' and to share where they found differences or concurrencies.

6) Minute Papers

On a blank sheet of paper, each student wrote an answer to a question about the video lecture in 2-3 minutes. The question usually asked the students to mention the main point of the lecture or to list what was the most difficult part in it.

7) Jigsaw

The class was divided into teams (of 3-5 students), each given a different assignment. Each member of a team was asked to complete a single part of the assignment. When every student completed his/her assigned task, the pieces were joined together to form a complete project.

8) Learning by Teaching

Students broke up into small groups, actively discussed a topic, and prepared the information so that they could teach it to the class.

9) The Fish Bowl

Each student wrote down one question concerning the information in the video lecture. Students put their questions in a bowl. The researcher then drew several questions out of the bowl and answered them for the class. Sometimes she asked the students to answer them.

10) Three-Step Interview

The researcher posed some questions. Students were divided into pairs. In each pair group, one student interviewed the other within specified time limits. The two then exchanged roles and conducted the interview again. Two pairs combined and the students introduced to the rest of the group the ideas posed by their partners.

\section{Copyrights}

Copyright for this article is retained by the author(s), with first publication rights granted to the journal.

This is an open-access article distributed under the terms and conditions of the Creative Commons Attribution license (http://creativecommons.org/licenses/by/4.0/). 